\title{
Note
}

\section{A Labor Theory of Legal Parenthood}

\author{
Shoshana L. Gillers
}

The right to raise one's child, free from governmental interference, is a fundamental liberty interest protected by a longstanding tradition of constitutional law. ${ }^{1}$ Protection of the parent-child relationship presupposes an understanding of legal parenthood-who is considered a parent in the eyes of the law, and why. Surprisingly, this prior question of legal parenthood, the foundation upon which the tradition of family privacy rests, is unresolved in case law. While scientific technology has made biological parenthood easier to determine, the law is ambivalent about the role biological parenthood should play in answering the question of legal parenthood. In determining legal parenthood, courts and legal commentators often turn to nonbiological factors such as marital ties, contractual ties, the best interests of the child, or parental desert. While each of these factors on its own, or in some combination, could provide a coherent theory of legal parenthood, current law does not reflect such a coherent theory, but rather stumbles between the various possibilities.

Where biological parenthood and marital status coincide, as in the case of the traditional nuclear family, conflicts over the rights to the newborn do not often arise. There are several common circumstances, however, in which biological parenthood and marital status do not coincide and intense conflict over a newborn can ensue. The case of unwed parents is a common

1. E.g., Pierce v. Soc'y of Sisters, 268 U.S. 510, 534-35 (1925) (affirming parents' right to "direct the upbringing and education of children under their control" and invalidating an Oregon statute that mandated public school attendance); Meyer v. Nebraska, 262 U.S. 390, 399 (1923) (defining Fourteenth Amendment liberty as including the right to "bring up children"). The Supreme Court reaffirmed this position most recently in Troxel v. Granville, $120 \mathrm{~S}$. Ct. 2054 (2000), by invalidating a Washington statute that allowed any person to petition for visitation rights at any time. The Court concluded that the statute infringed on parents' fundamental liberty interest to raise their children as they see fit. $I d$. at 2060. 
site of such conflict. Two people who do not necessarily have a long-term relationship, and do not necessarily plan to have children together, sometimes end up conceiving a child nonetheless. While both biological parents have contributed genetic material to the newborn, and the woman has chosen to carry the fetus to term, the marital tie is absent.

The extent of the biological father's right to be informed of the pregnancy and to have involvement in the child's life, as well as his responsibilities of support, have been vigorously debated by legal scholars. ${ }^{2}$ The Supreme Court has addressed the rights of biological fathers numerous times, ${ }^{3}$ and the Uniform Parentage Act offers an alternative account of legal fatherhood. ${ }^{4}$ Each of these various responses to the question of an unwed father's rights and responsibilities necessarily rests on a theory of what constitutes legal fatherhood. Those who would equate the biological father's right to the child with the biological mother's equate his genetic contribution with her contribution of genetic material and gestational production. Those who require something more of the biological father require more than biology for legal fatherhood, but not for legal motherhood.

Surrogacy agreements also sever biological parenthood from marital status. The genetic parents, those who have contributed the genetic

2. Compare Mary E. Becker, The Rights of Unwed Parents: Feminist Approaches, Soc. SERV. REV., Dec. 1989, at 496 (defending the exclusive rights of unwed mothers on feminist grounds), and Nancy S. Erickson, The Feminist Dilemma over Unwed Parents' Custody Rights: The Mother's Rights Must Take Priority, 2 LAW \& INEQ. 447 (1984) (defending the unwed mother's exclusive rights against the unwed father's due process, equal protection, and best interests of the child claims), with Elizabeth Buchanan, The Constitutional Rights of Unwed Fathers Before and After Lehr v. Robertson, 45 OHIO ST. L.J. 313 (1984) (arguing that the rights of fathers who are willing and able to parent are constitutionally protected), Deborah L. Forman, Unwed Fathers and Adoption: A Theoretical Analysis in Context, 72 TEX. L. REV. 967 (1994) (suggesting that unwed fathers' rights should be more vigorously protected), Mary L. Shanley, Unwed Fathers' Rights, Adoption, and Sex Equality: Gender-Neutrality and the Perpetuation of Patriarchy, 95 COLUM. L. REV. 60 (1995) (proposing that unwed fathers be given rights if they demonstrate their intention to parent), and Laurel J. Eveleigh, Note, Certainly Not Child's Play: A Serious Game of Hide and Seek with the Rights of Unwed Fathers, 40 SYRACUSE L. REV. 1055 (1989) (suggesting that acting to secure paternity rights should create a rebuttable presumption of parental fitness).

3. The Supreme Court's treatment of unwed fathers has not been consistent. See, e.g., Michael H. v. Gerald D., 491 U.S. 110 (1989) (upholding the constitutionality of the marital presumption against the claims of the putative biological father); Lehr v. Robertson, 463 U.S. 248 (1983) (upholding a state law that permitted adoption of a child born out of wedlock without biological father's notification or consent, as applied to a biological father who had no relationship with his two-year-old child); Caban v. Mohammed, 441 U.S. 380 (1979) (invalidating a New York statute that gave biological mothers, but not biological fathers, the right to veto adoptions of children); Quilloin v. Walcott, 434 U.S. 246 (1978) (holding that an unwed father, who in eleven years had not sought to register his paternity and had not had custody of the child, could not veto the mother's decision to allow her husband to adopt the child); Stanley v. Illinois, 405 U.S. 645 (1972) (ruling that an unwed father was entitled to a hearing before his children could be taken away from him after their mother's death).

4. UNIF. PARENTAGE ACT § 4(a)(5) (1973) (asserting that any man who "acknowledges his paternity" is the natural father). 
material, can be different than the gestational parent, the woman who has gestated the fetus, and different from the intending parents, those who have contracted and paid for the gestational services and genetic materials. Biological parenthood itself is fractured here, since the biological raw materials of genetics and the biological process of gestation can be separated. Biological parenthood and marriage are separated since the contractual parent is not married to the gestational parent, and sometimes not even to the genetic parent.

Surrogacy agreements have been the subject of much academic debate. ${ }^{5}$ Separate from, and often prior to, the question of enforceability of such agreements is the question of legal parenthood. Is the surrogate mother the original parent by virtue of having gestated the fetus? Are the genetic parents the original parents by virtue of having contributed the necessary genetic materials? Are the intending parents, those who orchestrated the creation of the newborn, the original parents by virtue of contract?

A theory of what constitutes legal parenthood must be applicable to all of these cases: the happily married couple, the unwed father, and the surrogate mother. In addition to being consistent, a theory of legal parenthood must award parenthood in a way that respects all parties' liberty and equality interests. ${ }^{6}$ In this Note, I propose a normative model of legal parenthood based on a Lockean labor theory of property that awards parenthood to the gestational mother, or those who commissioned her services. On this model, legal parenthood should be. awarded to the gestational mother, the one who has invested the most labor in the

5. Compare MARgaret JANE RAdin, CONTESTED COMmodities (1996) (arguing that surrogacy agreements devalue women and commodify children), ROBIN WEST, CARING FOR JUSTICE 55-59 (1997) (arguing that surrogacy agreements should not be treated as traditional commercial contracts), Anita Allen, Privacy, Surrogacy, and the Baby M Case, 76 GEo. L.J. 1759 (1988) (arguing against the enforceability of surrogacy agreements), and Dorothy Roberts, The Genetic Tie, 62 U. CHI. L. REV. 209 (1995) (suggesting that surrogacy agreements and the inflation of the genetic tie implicate racism), with Lori Andrews, Beyond Doctrinal Boundaries: A Legal Framework for. Surrogate Motherhood, 81 VA. L. REv. 2343 (1995) (proposing the enforcement of surrogacy agreements with certain legal protections), Richard Epstein, Surrogacy: The Case for Full Contractual Enforcement, 81 VA. L. REV. 2305 (1995) (arguing for full enforcement of surrogacy contracts), John Lawrence Hill, What Does It Mean To Be a "Parent"? The Claims of Biology as the Basis for Parental Rights, 66 N.Y.U. L. REV. 353 (1991) (arguing for the enforcement of surrogacy agreements and the assignment of parenthood to the contracting parents), and Marjorie Maguire Shultz, Reproductive Technology and Intent-Based Parenthood: An Opportunity for Gender Neutrality, 1990 WIS. L. REV. 297 (same).

6. The project of this Note is directly in contrast with the "interpretive approach" to resolving the new and various custody conflicts, as developed in Marsha Garrison, Law Making for Baby Making: An Interpretive Approach to the Determination of Legal Parentage, 113 HARV. L. REv. 835 (2000). Garrison's approach is to try to stay as close as possible to the common law in deciding the new cases made possible by technological advances. Id. at 873 . Thus, surrogacy should be illegal, because its common-law analog, baby-selling, is illegal. Id. at 873-74. This Note, instead of attempting to apply common law to new settings, questions the very foundations of the common law's approach to child custody and proposes a normative theory of legal parenthood that could be applied consistently to the various custody conflicts. 
developing fetus, and hence deserves parenthood the most. When the gestational mother has previously contracted out her labor, either completely, as through a surrogacy agreement, or partially, as through a marital agreement, the contract should be honored.

This Note focuses exclusively on the adult's perspective in the parentchild relationship. This perspective is somewhat anomalous in discussions of child custody. In most custody battles, the focus shifts from the adults' rights to those of the child. Various standards have been suggested and implemented in order to best serve the child's rights. The "best interests of the child" standard, or the "psychological parent" standard, or the "respecting the wishes of the child" standard, ${ }^{8}$ despite their differences and difficulties, are all similar in focusing on the child. The rights of the adults in these situations are not considered relevant.

Favoring children's rights over adults' rights makes sense intuitively. Treating the child as a means of protecting the adults' rights contradicts the Kantian aspiration of treating every person as an end, not a means to an end. ${ }^{9}$ Courts' tacit assumption that adults' rights are irrelevant to discussions of custody seems to follow in this Kantian tradition. What then justifies this Note's exclusive focus on the rights of adults in formulating a model of legal parenthood?

Despite the omission of adults' rights in many child custody discussions, lurking not too far beneath the surface is an implicit recognition of adults' rights to children. In custody battles that arise from divorce proceedings, family courts do not allow just any adult to argue his or her case for custody, but listen only to the parents. When women deliver children, they routinely take home their baby, without having to prove that of the millions of prospective parents, they alone will provide the best environment for the child.

Though not necessarily discussed openly, there is an implicit recognition in American law that adults have certain rights to children that must be protected. This is as it should be. While respecting children's rights is often an important factor, it is not always useful in making a custody determination. In some instances, determining the child's best interests is just not feasible: Ranking adults by their parenting ability would be a bureaucratic nightmare, and forbidding women from taking their children home would diminish the incentive to bear them. Moreover, any such

7. See generally JOSEPH GOLDSTEIN ET AL., BEYOND THE BEST INTERESTS OF THE CHILD (1973) (proposing a standard of custody allocation involving a determination of the "psychological parent," namely the adult with whom the child shares the greatest emotional ties).

8. See generally JEAN KOH PETERS, RePRESENTING CHILDREN IN CHILD PROTECTIVE PROCEEDINGS: ETHICAL AND PRACTICAL DIMENSIONS (1997) (proposing a standard of custody allocation involving a determination of the child's informed wishes).

9. IMMANUEL KANT, GROUNDWORK OF THE METAPHYSICS OF MORALS 38-41 (Mary Gregor trans. \& ed., Cambridge Univ. Press 1997) (1785). 
ranking would inevitably embrace certain prejudices and biases, for example, the idea that heterosexuality and affluence are markers of parenting excellence. ${ }^{10}$ Even where it is possible to determine the child's interests, those interests might not lead to a definitive conclusion, as the child might be equally happy with either potential parent.

Thus, there exist situations in which focusing on the child's interests does not always lead to a clear answer. It is in these situations that focusing on adults' rights can guide the custody determination. Adults' rights to children are relevant in discussions of what I call initial custody-deciding who takes the infant home from the hospital. In cases of initial custody, the issue at stake is who is to be considered the legal parent. Adults' rights are also sometimes relevant in cases of what I call subsequent custody-when legally recognized parents fight over who will continue to have custody over the child.

The question of legal parenthood, the focal point of this Note, arises immediately at the moment of the child's birth. At that moment, a determination of who would be the absolute best parent is simply not a feasible or a practical approach. When courts cannot determine the best interests of the child, they must turn their attention to the rights of the adults.

The Note proceeds as follows: Part I provides a summary of the current laws and theories surrounding legal parenthood. Part II presents the labor theory of legal parenthood, and Part III addresses some problems with the theory. Part IV applies the labor theory of legal parenthood to subsequent custody decisions by requiring legal parents continuously to invest emotionally and physically in their children's development in order to maintain custody. Part $\mathrm{V}$ suggests legislation that would encourage and facilitate such investment, and Part VI provides a brief conculsion.

\section{BACKGROUND LAWS AND CURRENT THEORIES OF LEGAL PARENTHOOD}

At common law, legal parenthood was closely linked to patriarchal notions of wife and child as property. As the law moved away from this patriarchal vision, it abandoned the patriarchal property understanding of legal parenthood, but did not replace it with an alternative theory of legal parenthood. While legal commentators have offered various theories, their theories are themselves incomplete, and the courts have not adopted any of them consistently. In this Part, I compare current laws governing legal

10. Such factors have been taken into consideration in surrogacy cases, with arguably unfair consequences. E.g., In re Baby M, 537 A.2d 1227, 1258 (N.J. 1988) (citing financial stability as one factor in determining the child's best interests). 
parenthood with the common-law tradition, and highlight the current lack of a coherent theoretical underpinning. I then describe and critique three recent attempts to offer a theoretical framework of legal parenthood.

\section{A. The Legal Background}

At common law, the critical factor in determining legal parenthood was marriage. A married woman's children belonged solely to her husband, ${ }^{11}$ who in turn had legal responsibility for them; an unmarried woman's children belonged to her alone, ${ }^{12}$ while the biological father had no legal responsibilities. ${ }^{13}$ Arguably, the emphasis on marriage as the criterion for legal parenthood stemmed from the propertied understanding of the marital relationship itself. A husband legally owned both his wife's person and her labor. ${ }^{14} \mathrm{He}$ thus owned the product of her person and her labor, her biological children. An unmarried woman owned her own person and her own labor, and therefore owned the product of both, her biological children. The common-law theory of legal parenthood depended on an understanding of marriage as a set of property relationships.

As property rhetoric has receded from descriptions of the marriage relationship, the theory of legal parenthood has likewise moved away from a marital property theory. It is not entirely clear what theory has replaced the marital property theory, but it seems to be a theory based on a combination of biology, functional parenthood, and marital status. ${ }^{15}$ In traditional nuclear families, husbands are no longer the sole custodians, but both husbands and wives are considered the legal parents of their joint offspring.

Unwed fathers are no longer treated as lacking legal ties to their offspring, but their interest is not completely protected. The Supreme Court

11. 2 JAMES KENT, COMMENTARIES ON AMERICAN LAW 170 (photo. reprint 1971) (1826).

12. Id. at 178.

13. Id. at $175-78$.

14. 1 WiLliam BLACKSTONE, COMMENTARIES *430.

15. Legal motherhood is generally determined by biology, but legal fatherhood is not. Marriage to the mother is still the best way to ensure custody, since the marital presumption trumps even a biological father's claim. Michael H. v. Gerald D., 491 U.S. 110, 121-30 (1989). In the absence of a marital tie, biological fathers must make some effort to register their interests with both the state and the mother. Lehr v. Robertson, 463 U.S. 248, 262 (1983) (holding that the biological father was not entitled to veto an adoption where he failed to register his paternity with the state). As the Supreme Court stated in Lehr,

[t]he significance of the biological connection is that it offers the natural father an opportunity that no other male possesses to develop a relationship with his offspring. If he grasps that opportunity and accepts some measure of responsibility for the child's future, he may enjoy the blessings of the parent-child relationship and make uniquely valuable contributions to the child's development. If he fails to do so, the Federal Constitution will not automatically compel a state to listen to his opinion of where the child's best interests lie.

Id. (citation omitted). 
has ruled that biological fatherhood is an important interest that deserves some modicum of protection, but that protection does not immediately translate into legal fatherhood. ${ }^{16}$ If the mother hides her pregnancy, the biological father must be vigilant about his interest and register his biological fatherhood with the state. The time frame for such paternity registries varies from state to state. When unwed fathers live with their offspring or develop extended relationships with them, their rights will generally be protected. ${ }^{17}$

Yet, some notion of legal fatherhood stemming from biology alone still lingers. Some states have gone beyond the minimum constitutional protection afforded unwed fathers in cases where biological mothers had given their consent for adoption, but the biological fathers had not. The courts returned the children to the biological fathers, on the theory that the biological fathers had the same rights to the child as the biological mothers. ${ }^{18}$ In several sperm donor cases, courts have granted the sperm donor legal parenthood despite his prior agreement to terminate parental rights. When the sperm donor knows the mother, courts are more likely to credit his claims of legal fatherhood. ${ }^{19}$ Finally, biological fathers can be, and often are, forced to pay child support even when they have no custodial interests. ${ }^{20}$

The question of legal motherhood has not been considered by the Supreme Court, and has thus been left to the discretion of the states. The surrogacy cases raise the question of legal motherhood as well as the question of transferability of legal parenthood. In the simplest of surrogacy cases, an individual or couple (the contracting or intending parents) ${ }^{21}$ contracts with a fertile woman (the surrogate mother) who agrees to be artificially inseminated, often with the contracting parent's sperm, to gestate and deliver the fetus, and to terminate her parental rights at birth. In the more complicated case of gestational surrogacy, the surrogate mother

16. See Lehr, 463 U.S. at 262.

17. E.g., Caban v. Mohammed, 441 U.S. 380 (1979) (finding in favor of the father where he had an extensive relationship with his child); Stanley v. Illinois, 405 U.S. 645 (1972) (finding for the father where he had lived with the children and their mother). This entire framework is void when the mother is married to another man. In the interest of preserving the marital unit, the Supreme Court has ruled that the husband's right to the child of an adulterous union trumps the biological father's ties. Michael H. v. Gerald D., 491 U.S. 110.

18. In re Kirchner, 649 N.E.2d 324 (III. 1995); Ex rel. B.G.C., 496 N.W.2d 239 (Iowa 1992).

19. See Jhordan C. v. Mary K., 224 Cal. Rptr. 530 (Ct. App. 1986); C.M. v. C.C., 377 A.2d 821 (N.J. Cumberland County Ct. 1977); In re Thomas S. v. Robin Y., 618 N.Y.S.2d 356 (App. Div. 1994); Leslie Joan Harris, Reconsidering the Criteria for Legal Fatherhood, 1996 UTAH L. REV. 461, 470-71.

20. See, e.g., Personal Responsibility and Opportunity Work Reconciliation Act of 1996 $\S 408$ (a)(2), 42 U.S.C.S. § 608(a)(2) (Law. Co-op. 2000).

21. A model that enforces surrogacy agreements enables not only infertile heterosexual couples but also homosexual couples to attain legal parenthood by paying for genetic materials and gestation. 
agrees to gestate an embryo supplied by the contracting parents, who have either produced or acquired the egg and the sperm. In the simple surrogacy case, the biological father's claim is pitted against the biological mother's claim and is supported by contract. In the gestational surrogacy case, where biological motherhood is fractured, the biological father and the genetic mother both claim against the gestational mother.

While the treatment of simple surrogacy and gestational surrogacy varies from state to state, ${ }^{22}$ the two most widely publicized cases have distinguished the types of surrogacy from one another. The well-publicized Baby $M$ case rested on claims of biological parenthood, while the Johnson case rested on a notion of intentional parenthood. In the Baby $M$ case, ${ }^{23}$ where Mary Beth Whitehead was artificially inseminated with Mr. Stern's sperm, the New Jersey court voided the surrogacy agreement as being contrary to public policy, and gave Mr. Stern and Mrs. Whitehead equal claims to the child. Having determined that both of the claimants were legal parents, the court determined which home was better suited to the best interests of the child. In the court's assessment, Mr. Stern and his wife could provide a better home for Baby M, and hence it awarded custody to Mr. Stern.

In Johnson $v$. Calvert, ${ }^{24}$ a California court implemented a novel conception of legal parenthood based on the intent standard developed by legal scholars Marjorie Maguire Schultz and John Hill. ${ }^{25}$ In Johnson, Mr. and Mrs. Calvert's embryo was implanted in Anna Johnson, who gestated and bore the child. The court looked to California parentage statutes and found that both genetic consanguinity and giving birth were determinative of legal motherhood. Since the statutes were of no help, the court adopted a different standard, the intent standard. When the genetic mother and

22. Only seventeen states and the District of Columbia have passed legislation regarding the enforceability or criminalization of surrogacy agreements. Six states have legislation that specifically holds surrogacy agreements enforceable, ARK. CODE ANN. \$ 9-10-201 (Michie 1998); FlA. STAT. ANN. $\$ 742.15$ (West 2000); 750 Ill. COMP. STAT. ANN. 45/6 (West 1999); NEv. ReV. STAT. ANN. § 126.045 (Michie 1998); N.H. REV. STAT. ANN. § 168-B:4 (1994); W. VA. CODE § 48-4-16 (2000), while eleven states and the District of Columbia criminalize or void surrogacy agreements or both criminalize and void such agreements, ARIZ. REV. STAT. § 25-218 (2000); D.C. CODE ANN. § 16-402 (1997); IND. CODE ANN. § 31-20-1-1 (Michie 1997); KY. REV. STAT. ANN. \& 199.590 (Michie 1999); LA. REV. STAT. ANN. \$ 9:2713 (West 1991); MICH. CoMP. LAWS ANN. § 722.855 (West 1993); NEB. REV. STAT. ANN. § 25.21,200 (1995); N.Y. DOM. REL. LAW \& 123 (McKinney 1999); N.D. CENT. CODE § 14-18-05 (1997); UTAH CODE ANN. § 76-7204 (1999); VA. CODE ANN. § 20-158 (Michie 1995); WASH. REV. CODE ANN. § 26.26.230, 240 (West 1997). Two states, while not indicating whether surrogacy agreements are enforceable or not, indicate that they are not criminal. ALA. CODE $\$ 26-10 A-33$ (1992); IOWA CODE ANN. $\S 710.11$ (West 1993).

23. In re Baby M, 537 A.2d 1227 (N.J. 1988).

24. 851 P.2d 776 (Cal. 1993).

25. When genetic consanguinity and giving birth do not coincide in the same woman, "she who intended to procreate the child ... is the natural mother." Id. at 782. In arguing for this position, the California Supreme Court directly relied on the work of three scholars, including Professors Hill and Shultz. Id. (citing Hill, supra note 5; Shultz, supra note 5). 
gestational mother are separated, she who intended to bring the child into the world would be considered the mother. The court therefore awarded custody to the Calverts, who had commissioned the gestation, and not to Johnson, who had gestated the Calvert's embryo.

The Baby $M$ court applied common law to settings of assisted reproductive technology differently than did the Johnson court. In Baby $M$, the court prioritized the biological relationship in determining that both the biological father and the biological mother were the parents. The Johnson court, by contrast, adopted a novel intent-based standard, and in so doing, dismissed the purely biological approach. The courts' approaches to the different statuses of the married couple, the unwed father, and the surrogate mother do not stem from a unified theory of legal parenthood. In the case of the married couple, legal parenthood stems from a confluence of presumed biological parenthood and marital status. In the case of the unwed father, legal fatherhood stems from his biological connection but requires either registration of interest or a relationship with the mother or child, while in surrogacy cases, legal fatherhood stems from biology alone. Both biological parenthood and the additional requirements of registration or relationship are irrelevant when another man is married to the mother. The courts seem to waver between a concern for the genetic tie and a desire to preserve the marital unit, and thus do not provide a clear theory of legal parenthood.

\section{B. Current Theories of Legal Parenthood}

Several legal commentators have attempted to fill the gap in the literature by proposing various theories of legal parenthood. Three distinct strands emerge, though only two have been fully developed. Commentators have proposed a genetic model of legal parenthood, an intent model of legal parenthood, and one scholar has proposed a property theory of custody that can be usefully applied to the question of legal parenthood. This Section examines the genetic model of legal parenthood, the intent model of legal parenthood, and the property model of custody. The Section tests these models for practicability and internal consistency as well as for their capacity to promote fairness and equality.

\section{The Genetic Model}

The genetic model asserts that individuals have a right to their genetic offspring. Thus, husbands and wives should have custodial rights to their marital children because those children are presumably their genetic offspring. An unwed father should have a custodial interest in his child 
because the newborn shares some of his genetic makeup. ${ }^{26} \mathrm{~A}$ genetic surrogate mother and the contracting-genetic father should each have a custodial interest. The genetic model can be seen as undergirding some of the cases discussed in the previous Section. In the Baby $M$ case, the New Jersey Supreme Court assumed that the biological father and the biological mother, Mr. Stern and Mrs. Whitehead, were the infant's parents and decided the issue with respect to the best interests of the child. Although the U.S. Supreme Court cases dealing with unwed fathers did not simply assume that biological fathers are automatically legal fathers, the unwed fathers in all of those cases argued for that simple equation. ${ }^{27}$

There are two different versions of the genetic argument: the property version and the "best interests of the child" version. In the property version, adults' rights to their biological children stem from the property interest they have in their genes. ${ }^{28}$ In the "best interests of the child" version, adults' rights to their biological children are justified because children are better off with their genetic parents. ${ }^{29}$ Neither of these two versions of the genetic argument is ultimately compelling.

The property version of the genetic model is not completely satisfying primarily because it does not adequately account for labor contributed by both the mother and father. For example, Kermit Roosevelt, a proponent of the property version of the genetic model, argues that adults' rights to children stem from adults' rights in their reproductive materials. ${ }^{30}$ Roosevelt argues that men and women have property rights in their sperm and eggs and thus have property rights in the children that develop from their sperm and eggs. ${ }^{31}$ Roosevelt also considers such property rights alienable and would hence award legal parenthood to whomever held the

26. Current Supreme Court jurisprudence does not dictate that the unwed father's genetic tie is sufficient to guarantee him legal parenthood in the absence of a further relationship with the child. It does, however, note that the genetic tie grants the unwed father the opportunity to develop a relationship with the child. In the words of the Court: "The significance of the biological connection is that it offers the natural father an opportunity that no other male possesses to develop a relationship with his offspring." Lehr v. Robertson, 463 U.S. 248, 262 (1983).

27. See Michael H. v. Gerald D., 491 U.S. 110, 119 (1989) (arguing that the marital presumption unlawfully terminates the biological father's liberty interest in the relationship with his child); Lehr, 463 U.S. at 255 (arguing that allowing an adoption to proceed without his consent denies a biological father's liberty interests in his relationship with his child); Quilloin v. Walcott 434 U.S. 246, 252 (1978) (same).

28. Kermit Roosevelt III, The Newest Property: Reproductive Technologies and the Concept of Parenthood, 39 SANTA CLARA L. REV. 79 (1998) (arguing that parenthood should be assigned to the genetic parents because of their property rights in their genes).

29. See, e.g., Anders Eriksson \& Åke Saldeen, Parenthood and Science-Establishing and Contesting Parentage, in PARENTHOOD IN MODERN SOCIETY: LEGAL AND SOCIAL ISSUES FOR THE TWENTY-FIRST CENTURY 75 (John Eekelaar \& Petar Sarcevic eds., 1993) (arguing that, on the basis of children's best interests, biological fatherhood should coincide with legal fatherhood in as many cases as possible).

30. Roosevelt, supra note 28 , at 80,88 .

31. Id. at 96-104. 
property rights in the raw materials before gestation. ${ }^{32}$ This analysis is fundamentally flawed because it overlooks the crucial steps that occur between the production of reproductive materials and the emergence of a newborn, namely, gestation and childbirth. It is not simply the case that whoever owns the raw materials owns the finished product. Any property theory must account for the labor that is required to develop raw material into the finished product; in many cases, the person who performs the labor, or the person who commissioned the labor, owns the finished product. It is simply not the case that applying property theory to the question of child custody dictates that the owners of the reproductive materials, and not the suppliers of gestational labor, may claim custody of the child.

What I have dubbed the "best interests of the child" version of the genetic argument seems to be rooted more in a widely held and deeply ingrained notion that children are just better off with their biological parents than in empirical evidence that this is in fact the case. Popular myths abound describing the disadvantages to being raised by anyone other than one's biological parents. Scholars have critiqued the studies that purport to support these claims in the adoption context as misrepresenting the evidence to comport with popular intuition. ${ }^{33}$ In fact, the evidence demonstrates that adoptive situations work to the advantage of all involved. ${ }^{34}$ The "best interests" version of the genetic model rests on faulty empirical assumptions and relies too heavily on popular myth, and thus does not provide a reasoned theory of legal parenthood.

\section{.2. The Intent Model}

Modern reproductive technology has made several collaborative reproductive schemata available to the infertile. The arrangements work well as long as there are no regrets, but when parties to the agreement renege, the courts have not always enforced the contractual intentions. While many courts have ignored the contractually expressed intentions of the parties and assigned legal parenthood according to biological parenthood,$^{35}$ some scholars have suggested that intention be considered a sufficient condition of legal parenthood in collaborative reproductive arrangements. ${ }^{36}$

As a result of innovations in reproductive technology, it is possible to have several potential parents of a given child, each claiming to have some

32. Id. at 116-17.

33. E.g., Elizabeth Bartholet, Family Bonds: AdOPTION aNd the POlitics of PARENTING 174-81 (1993) (critiquing studies that highlight negative outcomes of adoption).

34. Id. at 174-75.

35. See, e.g., In re Baby M, 537 A.2d 1227, 1258 (N.J. 1988).

30. See, e.g., Hill, supra note 5; Shultz, supra note 5. 
right to parent. The traditional surrogacy context involved only three players: a fertile husband, an infertile wife, and a fertile second woman who agrees to be impregnated by the husband and turn over the child to the couple in exchange for a fee. Since one woman can now gestate another woman's egg, and since sperm banks are widely available, it is now possible to have many potential parents: an individual or couple (the contracting or intending parents), a sperm donor and an egg donor (the genetic parents), and a gestator (the surrogate mother).

Intent theorists would award legal parenthood to those who have intended to bring the child into the world, namely, those who have orchestrated the reproduction. ${ }^{37}$ These scholars apply the intent model to the artificial reproduction context only, and not to the traditional coital reproduction context. In the surrogacy context, therefore, intent theorists argue that the child should go to those who originally intended to bring the child into this world, namely, the contracting parents, or, as intent theorists would call them, the intending parents.

At the core of the intent theory is a basic desire to honor contractual agreements. ${ }^{38}$ While honoring contract is a worthy goal, the intent model is limited as a theory of legal parenthood. First, as Hill and Shultz both concede, the model does not govern all cases. Shultz explicitly states that she only intends her model to apply to collaborative reproductive agreements, ${ }^{39}$ while Hill states that it is relevant only in cases of intentional reproduction. ${ }^{40}$ Second, and more basic, contract does not fully explain a theory of parenthood even for the limited case of collaborative reproductive agreements. In traditional contract law, before one contracts to sell a widget, one must have a right to the widget in the first place. One cannot sell what one does not own. A theory of parenthood based on contract presupposes a theory of parenthood based on property.

Neither Hill nor Shultz advocates a theory of parenthood based on property, and neither explicitly states where the initial entitlements lie. They both assume that the contractual agreements involved in collaborative reproductive schemes trade actual rights and entitlements, ${ }^{41}$ but neither explains the source or the locus of those rights. While both Shultz and Hill decry courts' reliance on a biological theory of parenthood, ${ }^{42}$ in the absence of contractually explicit intentions, they seem to rely on biology as well. Hill specifically states that, while intent is a sufficient condition for legal parenthood, it is not a necessary one, and, where intent is absent, biology

37. E.g., Hill, supra note 5; Shultz, supra note 5.

38. Hill, supra note 5, at 415-16, Shultz, supra note 5, at 323.

39. Shultz, supra note 5 , at 324 .

40. Hill, supra note 5, at 387.

41. Id. at 415-16; Shultz, supra note 5, at 323.

42. Hill, supra note 5, at 388-94; Shultz, supra note 5, at 316-18. 
suffices. ${ }^{43}$ Moreover, honoring contractual intentions might very well be part of a theory of legal parenthood, but on its own it is incomplete. It might be appropriate to respect parties' wishes in transferring their entitlements to a developing fetus, but a complete theory must answer the prior question of how those entitlements are established. These inadequacies show that the intent theory provides an incomplete account of legal parenthood.

\section{The Property Model}

A property theory of legal parenthood fills the gap left by the contractor intent-based theory. On a property theory, entitlement to legal parenthood is achieved by acquiring property-like rights in children. The difficult question that a property theory of legal parenthood must answer is the question of true acquisition of property rights. The property version of the genetic model, advanced by Roosevelt, views property entitlement in children as stemming from property rights in the raw materials of reproduction. ${ }^{44}$ As discussed above, that model is flawed because it fails to account for the work of gestation and labor that is necessary to develop the raw materials of reproduction into a child. Katharine Baker has advanced a model of custody allocation based on a labor theory of property that can be usefully applied to the prior question of legal parenthood.

\section{a. Baker's Property Model of Custody Allocation}

While Baker's labor theory of custody is primarily a means of distinguishing between the custodial rights of legal parents, this Note addresses the prior question of what constitutes legal parenthood. The basic insight of her model, however, that rights to children should be allocated according to notions of Lockean notions of labor-desert, can be usefully applied to the question of legal parenthood, with certain modifications.

Baker proposes a system of custody allocation based on emotional investment in children. ${ }^{45}$ Her theory focuses primarily on subsequent custody situations, but she addresses initial custody as well. Baker argues for a Lockean labor theory of custody: Parents acquire property rights in their relationships with their children by virtue of the emotional work they do in raising them. Custody is the reward for the investment in childrearing. ${ }^{46}$

43. Hill, supra note 5 , at 387 .

44. See supra notes $30-32$ and accompanying text.

45. Katharine K. Baker, Property Rules Meet Feminist Needs: Respecting Autonomy by Valuing Connection, 59 OHIO ST. L.J. 1523 (1998). For a related theory, suggesting that legal fatherhood be based on functional parenthood, see Leslie Joan Harris, Reconsidering the Criteria for Legal Fatherhood, 1996 UTAH L. REV. 461.

4ó. Baker, supra note 45 , at 1580-81. 
This model of custody allocation is justified primarily as a means of protecting the rights of women who disproportionately do the work of child-rearing and further, of protecting divorced custodial parents from state interference. Under the current system of custody allocation, custodial rights are allocated on the basis of the "best interests" standard, which usually, though not necessarily, awards custody to the primary caretaker. The greater problem is that the divorced custodial parent is not thereafter afforded the same privacy protection from state interference that is afforded married couples. The state, of its own volition, or at the behest of the noncustodial parent, can contest the custodial parent's decisions on childrearing. Baker intends her labor theory of custody to distribute custodial rights more fairly and, more importantly, to minimize the interests of the noncustodial parent in order to protect the decisions of the custodial parent.

Instead of attempting to apply the fuzzy "best interests" standard, Baker would have courts compare the relative emotional investment of the parents, and award custody to the greater investor. Baker would then prevent the state from interfering with the custodial parent's decisions, but would afford the custodial parent the same privacy protection the state affords married couples. The noncustodial parent's rights would thereafter be limited to a reversionary interest in the child-if the custodial parent should die, custody would revert back to the noncustodial parent.

Although Baker addresses primarily the case of subsequent custody, she applies the emotional investment model of custodial rights to the case of initial custody as well. She would award custody of the newborn child solely to the gestating mother, the person who by virtue of her unique physical connection to the child has the greater emotional connection as well. ${ }^{47}$ Thus, at birth, the gestational mother would be afforded complete autonomy in making decisions for the child, while the biological father, who at that point has not invested emotionally, would have no recognizable property interest and thus no custodial interest. ${ }^{48}$ Baker would allow people other than the gestational mother to invest in the child and thereby gain custodial interests, but only if the investment is made with the permission of the mother. Baker identifies marriage and adoption as two ways of registering an interest in the child and publicly recording the mother's permission to invest. ${ }^{49}$

47. Id. at 1586 .

48. Id.

49. Id. 


\section{b. Applying Baker's Model to the Question of Legal Parenthood}

Baker's model is intended to be a model of custody allocation, not a model of legal parenthood, which is the central theme of this Note. Focusing on custody allocation, and focusing primarily on the case of subsequent custody, influences the choice of what type of work counts as investment in the adult-child relationship. As a model of custody, the paradigmatic case is that of divorcing parents with disproportionate emotional investment in the child. In keeping with her desire to protect women's disproportionate contribution to child-rearing, Baker credits only emotional investment and discounts monetary investment. In applying her model of custody allocation to the case of initial custody, Baker also credits emotional investment only and discounts monetary and genetic investment. Thus, the gestational mother is awarded custody of the newborn because her unique physical connection affords her greater emotional connection. Contracts to pay the gestational mother for her services, and hence invest monetarily in the fetus, are void, as are claims by biological fathers who have contributed genetically.

While the emotional investment standard might accurately capture the work of child-rearing, it does not fully capture the work of childbearing. There is some emotional component to the work a pregnant woman does in bearing a child, but gestation and childbirth are primarily hard physical labor. If emotional investment is not the appropriate measure of investment in childbearing, a labor theory of legal parenthood should reconsider the rights of other contributors to the childbearing process, the rights of monetary and genetic investors. Simply applying the emotional investment standard misses the significant difference between the question of custody allocation and the question of legal parenthood. A theory of legal parenthood based on a labor-investment theory must reconsider what type of work counts to develop a property interest in the developing fetus.

The three theories examined up to this point have failed to give a complete and coherent account of legal parenthood. The property version of the genetic model of legal parenthood is incomplete because, although it recognizes property in reproductive materials, it does not recognize the work required to develop those raw materials into a child. The intent model of legal parenthood is incomplete because in honoring parties' contracts regarding their entitlements to children, it simply presupposes a method of obtaining initial entitlements. The labor theory of custody is incomplete as a model of legal parenthood since it relies on the emotional investment of child-rearing and does not capture the work that people do in childbearing. The next Part proposes a labor theory of legal parenthood that honors individuals' rights in their reproductive materials, accurately describes the 
labor of childbearing, and respects the intentions that are expressed in contracts.

\section{A LABOR THEORY OF LEGAL PARENTHOOD}

This Part proposes the central contribution of this Note: a labor theory of legal parenthood. In brief, this Part argues that the labor-desert theory of property, because it respects the property rights of the genetic parents, rewards the work of reproduction, and honors the contractually expressed intentions of the rights-holders, provides a fair and just basis for allocating rights to legal parenthood. Drawing on property concepts is appropriate and helpful in the context of deciding how to allocate legal parenthood. Property law is concerned with the allocation of resources and entitlements, and deals specifically with how to adjudicate competing claims. The labor theory of property is uniquely appropriate to the context of reproduction, because of the centrality of labor in the development of children.

Property scholars consider Lockean labor theory to be foundational to modern property law. ${ }^{50}$ According to this theory, entitlement to an object flows directly from the productive labor that a person puts into the object. The theory starts from the premise that people own their own bodies and moves to the assertion that people own the labor that stems from their own bodies. The final step is that people therefore own the fruits of their productive labor. The labor theory of property provides a merit-based method of allocating the fruits of labor. It distributes those fruits unequally, but does so in a manner that can be justified by merit. ${ }^{51}$

The paradigmatic case of labor property acquisition occurs in a state of nature: A field hitherto belonged to no one, but a person may acquire it by mixing her labor with it. The argument appeals to notions of fairness-a person who works for something is entitled to reap the fruits of her labor.

50. Locke's theory of property can be found in JOHN LOCKE, TwO TREATISES OF GovernMENT 285-302 (Peter Laslett ed., Cambridge Univ. Press 1988) (1690). For a thorough explanation of Locke's views on property, see, for example, David P. Ellerman, On the Labor Theory of Property, 16 PHIL. F. 293 (1985).

51. Addressing all the difficulties and intricacies of the Lockean labor theory is beyond the scope of this Note. For a comprehensive discussion of the problems with the theory, see STEPHEN F. MUNZER, A THEORY OF PROPERTY 254-89 (1990). Two issues are particularly relevant to the reproduction context, and each will be addressed briefly. First, a common critique of merit-based property allocations is that people do not deserve the initial endowments that allow them to labor. See JOHN RAWLS, A THEORY OF JUSTICE 86-87 (1971). This critique is particularly relevant to the reproduction context because women are uniquely able to gestate, while men are not. One answer to this critique is that men's sperm is also uniquely necessary for reproduction, so they can bargain with women for the fruits of reproduction. Second, the Lockean proviso limits labor acquisition of property to situations where there is enough left for others to acquire. Locke's theory is particularly applicable in the reproductive context, where many people have some reproductive potential and can collaborate with others to reproduce. 
What distinguishes a worker's claim to the field over her neighbor's is the hard work that the worker has invested in the field.

Applying the labor theory of property to newborns has a similar appeal to fairness. Gestation is labor-intensive. It seems only fair to award custody of the final product to the one who has labored for it. Applying this theory to the different cases of initial custody conflict, however, is more difficult than simply applying the basic insight that labor investment earns entitlement. The following Sections apply this basic insight to the difficult cases of conflict.

\section{A. Unwed Fathers}

While in Locke's paradigmatic case, the raw materials were previously unassigned, in the context of reproductive labor, the raw materials were in fact assigned. Sperm necessarily emanates from some man, eggs necessarily emanate from some woman, and some woman must perform the gestational labor. This situation veers from Locke's paradigmatic case and thus raises a question for the labor theory. Does the fact that some of the raw materials belong to another bar labor from earning property rights to the final product? There are two ways to address this question. First, it is plausible to argue that sperm, once physically transferred, is no longer considered to belong to the unwed father. The unwed mother thus gestates material that belongs to no one, and the case once again resembles the paradigmatic unowned field. Alternatively, the doctrine of accessions, a principle of property that stems from the Lockean labor theory, can be used to explain how the woman's gestational labor nonetheless earns her sole entitlement to parental rights.

\section{The Raw Materials of Reproduction}

The key question in custody cases involving unwed fathers is the question of ownership of the raw materials of reproduction. It is clear that the biological mother owns both her egg and her gestational labor. What is unclear is the status of the sperm. In cases of casual sex, where the biological parents do not have a long-term relationship and have never discussed the possibility of conception, does the biological father retain an interest in the sperm that he physically transfers to the biological mother? Absent an expression of his intention, does the biological father retain a proprietary interest in the sperm once it leaves his body?

Without contractual arrangements indicating intent to the contrary, acts of physical transfer of property are generally understood to imply transfers 
of ownership. The only question that generally arises is whether the transfer was gratuitous, or, alternatively, involved an implied promise to pay. ${ }^{52}$ It seems likely that physical transfer of sperm is gratuitous. After casual sex, men do not go around collecting their sperm and do not generally seek payment for the sperm transfer. Further, men generally do not inquire after every sexual encounter to determine if conception had ensued and are generally not diligent about seeking to support children of their casual sexual encounters. ${ }^{53}$ Assuming then, that men gratuitously transfer their sperm during casual sex, women own the raw materials of reproduction and personally perform the work of gestation. Women who conceive as a result of casual sex thus acquire legal parenthood, while men who donate the sperm in such encounters do not.

\section{The Doctrine of Accessions}

Alternatively, if men do retain proprietary interests in their sperm even on physical transfer during casual sex, they are still a long way off from having earned legal parenthood. The basic insight of the labor theory of property is that ownership of the raw materials of production does not necessarily imply ownership of the final product. Labor is necessary to warrant ownership. The unwed father has not gestated the fetus, but has simply contributed part of the raw materials, while the unwed mother has contributed both raw materials and gestational labor. It would seem unfair to award legal parenthood to the unwed father simply because he contributed half of the genetic material. ${ }^{54}$

The case of developing another's property is dealt with in property law by the doctrine of accessions. ${ }^{55}$ When $A$ has, in good faith, developed $B$ 's raw materials into a finished product, and thereby significantly increased the raw materials' value, title vests not in $B$, the original property owner, but in $A$, the producer. ${ }^{56}$ This doctrine is generally employed to prevent

52. See Boston Ice Co. v. Potter, 123 Mass. 28 (1877) (holding that the defendant's receipt of ice did not constitute an implied promise to pay the plaintiff because the defendant had no knowledge that the plaintiff had delivered the ice).

53. The presence of so many single mothers raising children without the help of the biological fathers is one indication of the tendency of many men not to acknowledge the consequences of their sexual activities. In 1998, 17\% of all households were headed by women, U.S. Census Bureau, Statistical ABSTRaCT OF THE UNITED STATES 60 thl.70 (1999), and $30 \%$ of these female householders had never been married, id. at 61 tbl.72.

54. Even his genetic contribution is arguably less significant than hers. While eggs and sperm supply the same percentage of genetic information, eggs supply much more in the way of food reserves. RiCHARD DAWKINS, THE SELFISH GENE 141-42 (1989). Futhermore, as reflected in the relative market prices of sperm and eggs, there is a much greater supply of sperm than of eggs. The egg, then, is the more valuable contribution.

55. Ray ANDREWS Brown, The LaW OF PERSONAL Property 51-57 (2d ed. 1955).

56. In Wetherbee v. Green, 22 Mich. 311 (1871), Wetherbee had, in good faith, cut Green's timber and converted it into barrel hoops that were worth over twenty-eight times the value of the 
what would otherwise be considered "gross injustice." 57 It would seem wrong to award title of an item of increased value to one who merely owned the raw materials but did none of the intensive labor required to develop them. Rather than awarding title to the original owner, title is awarded to the developer, who must reimburse the original owner for the original value of the raw materials.

When a woman gestates her own egg with another's sperm, the ensuing battle over the developed child seems an appropriate case for the doctrine of accessions. It would seem a gross injustice to award custody of the child to the man who did not participate in the nine months of pregnancy or in the arduous labor and delivery, but merely contributed one small piece of the necessary raw materials. Title should go to the woman, who has done the reproductive labor, and she should be required to reimburse the sperm donor at the going market rate for sperm. ${ }^{58}$

The unwed father, therefore, has either little or no claim to his genetic child, conceived through casual sex. Either he is seen as having gratuitously transferred his sperm, in which case he has absolutely no claim to the developed child, or his only claim is to be reimbursed for his sperm at the going market rate.

The labor theory of legal parenthood incorporates both the insight of Roosevelt that the genetic contributions must be recognized and accounted for, and the insight of Baker that the labor of childbearing is what determines property rights in the fetus. The labor theory moves beyond Roosevelt by prioritizing labor over raw material ownership, and moves beyond Baker by recognizing that the importance of childbearing for a Lockean labor model is the actual physical labor of gestation and childbirth, and not the emotional connection that is its by-product.

\section{B. Surrogacy}

The case of surrogacy agreements raises further questions for a labor theory of property. In the surrogacy context, the surrogate mother does all of the work of gestating the fetus. Does the act of gestation entitle her to rights in the child, just as it did the unwed mother? One important factor, the presence of a contract, distinguishes the surrogate mother from the unwed mother. The contracting parents hired her gestational services and

original timber. Green sued Wetherbee for replevin, and the Michigan Supreme Court held that Wetherbee's labor in transforming the timber had given him title to the barrel hoops. Green could sue him only for unintentional trespass.

57. E.g., Eaton v. Langley, 47 S.W. 123, 125 (Ark. 1898) (concluding that a good-faith conversion of another's timber into cross ties worth only six times the original timber did not constitute "gross injustice" when the cross ties were returned to the original owner).

58. The value of the sperm can be determined by comparing it to comparable sperm sold by a sperm bank. 
provided her with the sperm, and possibly the egg, for the purpose of gestating a child for them, in exchange for a fee.

Surrogacy agreements thus bring up an issue familiar to Lockean labor theory: Is personal labor alienable? In other words, if $A$ hires $B$ 's services, there is a degree of uncertainty as to which one owns the labor and thus the products of that labor. Capitalist property principles assume that labor can be sold and that rights to the developed product accrue to those who hire laborers. ${ }^{59}$ Thus, to answer the question above, when $A$ hires $B$ 's services, $A$ can be said to own both the labor and the products of that labor.

Since labor can be rented, the ownership of the finished product accrues to those who have provided the raw materials and hired the productive services. In the case of the surrogacy agreement, ownership thus accrues to the contracting parents, who have provided the raw materials of reproduction and have hired the gestational services. Legal parenthood never accrues to the surrogate mother, in the same way that legal ownership of the widgets never accrues to the hired widget worker.

In this respect, the labor theory of legal parenthood differs significantly from Baker's property model of custody allocation. Baker, motivated by her focus on the subsequent custody case, limits property-producing investment in the developing fetus to emotional investment. The focus on emotion stems from an assumption that emotion is the more appropriate type of labor to recognize in developing rights to a child, because emotional investment corresponds naturally to the relationship that one develops with a child. An emotional relationship with a child is not something that can be transferred to another person at any price. It is therefore inappropriate to talk of selling one's rights to a child. Once one recognizes, however, that the gestating mother's investment in the developing fetus is not primarily emotional, and focuses instead on the actual physical labor that the woman does in bearing the child, the notion of transferring that right makes sense. Gestating mothers acquire rights to children by virtue of the productive labor that they perform, not by virtue of the emotional relationship they have with the fetus. They can therefore sell those property rights to anyone else.

In recognizing that labor can be sold, the labor theory of legal parenthood incorporates the insight of the intent model of legal parenthood, which respects the contractual intentions involved in collaborative reproductive agreements. The labor model completes the intent model by not merely presupposing entitlements to legal parenthood, but by positing a method of acquisition. This model, furthermore, goes beyond the intent

59. Ellerman, supra note 50, at 318-22. Marxists argue that labor is inalienable, and that rights to the developed product necessarily accrue to the laborer. Id, at 296-97. This Note chooses to follow the capitalist understanding of Locke and assumes that labor can be rented. 
model because it respects contractual intentions in all cases of legal parenthood, and does not limit the enforcement of contracts to cases of assisted reproductive technology. The context of married couples provides an additional case of reproductive contracting that the labor model respects and enforces.

\section{Married Couples}

The case of the married couple might be viewed initially as analogous to the case of the unwed couple. What is common to both cases, by virtue of biology and the limitations of technology, is that the woman always gestates, and hence always does the reproductive labor that results in the acquisition of title. However, the marriage contract provides a useful way of distinguishing between the two cases.

While there has been criticism of the practice of inferring contractual obligations from marital status, ${ }^{60}$ it is clear that under current law married persons are said to assume certain contractual obligations towards each other by virtue of their marital status. Children partially motivate the state's interest in marriage, and procreation is considered to be part of the marital contract. $^{61}$ It would make sense to infer an agreement to share joint custody over the marital children from the marital status.

In the context of marriage, it would therefore be inaccurate to describe the sperm transfer as gratuitous. It is more plausible to infer an implied contract: sperm transfer in exchange for joint custody in the child. The agreement could be viewed as an actual contract, similar to the one expressly made between the surrogate mother and the contracting parents. The husband could be seen as contracting with his wife for joint custody, in exchange for sperm transfer alone, or additionally, in exchange for emotional, physical, or financial support during pregnancy and delivery. ${ }^{62}$

60. See LeNORE J. WeITZMAN, The MARRIAGe CONTRACT (1981) (arguing against inferring contracts from marital status and suggesting that couples instead form their own contractual agreements); Marjorie Maguire Shultz, Contractual Ordering of Marriage: A New Model for State Policy, 70 CAL. L. REV. 204 (1982) (arguing for the enforcement of interspousal contracts).

61. See Miller v. Miller, 228 N.Y.S. 657, 657 (Sup. Ct. 1928) ("Marital intercourse, so that children may be born, is an obligation of the marriage contract, and is the foundation upon which must rest the perpetuation of society." (quoting Mirizo v. Mirizo, 150 N.E. 605, 607 (N.Y. 1926))).

62. In analyzing the three different scenarios of unwed fathers, surrogate mothers, and married couples, this Part has focused on situations that are arguably overly simplistic. On one end of the spectrum, there are cases of surrogate motherhood and marriage, where contractual intentions can be easily inferred. On the other end, there are cases of casual sex, where contractual intentions seem to be present. In concentrating on the two ends of the spectrum, I do not mean to imply that there are no gray areas in between. There are certain to be cases of cohabitation that fall in between casual sex and marriage, where a case can be made for contractual intentions. In such situations, biological fathers who seek custody will have to rely on notions of implied contract to make their case for prior contracts for custody. 
In rewarding the labor of childbearing with parenthood, in recognizing and addressing the property rights of genetic contributors, and in honoring the contractually expressed intentions of those who wish to transfer their entitlements, the labor theory of legal parenthood combines the best aspects of the genetic and intent models of parenthood with the basic insight of Baker's labor theory of custody. The resulting model dictates that in the absence of contract, the gestating mother is the exclusive legal parent, but that in the presence of contract, legal parenthood is awarded according to the contractually expressed intentions of the rights holders.

\section{PROBLEMS WITH THE LABOR THEORY OF LEGAL PARENTHOOD}

This Part discusses two possible critiques of the labor theory of legal parenthood. The first is a normative critique, the second a consequentialist critique. The first addresses the model's incorporation of surrogacy agreements from the perspective of the anticommodificationist. The second addresses possible negative consequences of the model on the plight of single women and their children.

\section{A. Commodification and the Devaluation of Personhood}

Any theory that advocates the enforcement of surrogacy agreements has to contend with the wealth of feminist and anticommodificationist literature that argues against the enforcement of such agreements. This Note's labor theory of legal parenthood respects the contractual intentions of women who agree to hire out their gestational services, and understands them to be transferring their rights to the fruits of their labor, either completely through surrogacy contracts, or partially through marital agreements. In fact, gestational mothers' ability to contract out their reproductive services is the only means through which men gain legal parenthood. Since the alienability of reproductive services is so central to the labor theory of legal parenthood, this Note must contend with those who argue that reproductive services are not for sale.

Margaret Jane Radin has attacked laws that, she argues, lead to the devaluation of personal integrity and commodification of entities that should be beyond the reach of the market. ${ }^{63}$ She has attacked surrogacy agreements for both devaluing the personal integrity of the surrogate mothers and commodifying the children themselves. This Section addresses Radin's critique of surrogacy agreements. Radin's larger project is to deny

63. MARgaret JANE RADIN, CONTESTED COMMODItIES (1996) [hereinafter RADIN, CONTESTED COMMODITIES]; Margaret Jane Radin,. Market-Inalienability, 100 HARV. L. REV. 1849 (1987). 
the proposition that all goods are property and that all human interaction is contractual. She attacks Richard Posner and Gary Becker as universal commodifiers, those who see everything through the lens of property law. ${ }^{64}$ Radin argues that in addition to goods that are properly commodifiable, there are two other classes of goods: those that should never be commodified, and those that can be partially commodified. According to Radin, commodifiability depends to a large extent on whether the goods in question are fungible property or personal property. ${ }^{65}$ The most extreme example of personal property is one's own body; the most extreme example of fungible property is money. An example of a good that is incompletely commodifiable for Radin is one's labor, as it stems from one's body but can be disconnected from it. ${ }^{66}$ She characterizes the harm of commodification of personal property as threatening Kantian personhood by treating people as means and not as ends in themselves. ${ }^{67}$ Commodification thus denigrates personhood and wrongly affects our perceptions of others.

Much of what Radin classifies as personal property involves commodities owned and marketed uniquely by women. ${ }^{68}$ Marketing women's bodies, or women's special abilities, is damaging to women because it makes them seem fungible, hence mistakes them for means and not ends, and denigrates their personhood. Radin considers the commodification effects of two women's markets, the prostitution market and the surrogacy, or in her terminology, baby-selling market. ${ }^{99}$ These markets present a Catch-22 for the feminist anticommodificationist, or a "double bind" in Radin's terminology. ${ }^{70}$ The unfortunate existence of these markets has resulted in the denigration of women, while prohibiting them limits women's autonomy. Radin recommends the decriminalization and the unenforceability of prostitution contracts, that is, contracts to sell sexual services, ${ }^{71}$ but advocates the criminalization of surrogacy. ${ }^{72}$ She distinguishes between the two primarily because surrogacy involves the commodification of not only women, but children as well. ${ }^{73}$

Radin's critique of surrogacy rests on faulty analogical reasoning and incorrect empirical assumptions. Radin equates surrogacy with babyselling, while the two situations are in fact very different. She assumes that the problems of baby-selling will necessarily inhere in surrogacy, while the

64. RADIN, CONTESTED COMMODITIES, supra note 47, at 12-13.

65. Id. at $58-60$.

66. Id. at 102-14.

67. $I d$. at 84 .

68. Id. at 127 .

69. Id. at 131-53.

70. Id. at 127 .

71. Id. at 134-35.

72. Id. at $136-44$.

73. Id. at $137-39$. 
differences between the two situations are actually relevant. She further assumes that the commodification harms she fears will actually occur, while in fact, studies of surrogacy agreements show that they have not occurred.

The differences between surrogacy agreements and baby-selling are important to flesh out. While baby-selling involves the sale of an actual human being, surrogacy contracts involve the commissioning of products and services for the creation of a child. The contracting parents do not walk onto the scene after the child is born and choose whether to purchase it. Rather, they are involved in the creation process, and plan and choose to have a baby. Surrogacy agreements are more like other forms of assisted reproductive technologies, where infertile people who want to create children avail themselves of nontraditional methods made possible by developments in modern technology. Instead of paying a doctor to create an embryo in a petri dish, they pay a woman to gestate the embryo for them.

The presence of money does not mean that babies are being sold, but rather that the services of baby production are being sold. Money itself is no stranger to reproduction. Routine doctor visits, hospital services, not to mention fertility treatments, all cost money. The fact that the money is not going to a doctor or hospital, but rather to a woman who is able to provide reproductive services on her own, does not make money any more significant.

Setting aside the question of whether surrogacy is more like other forms of assisted reproductive technology or more like baby-selling, Radin's empirical assumption that surrogacy harms women and children has not been proven. Prostitution, to which many women turn out of economic necessity, might be said to be an affront to personal integrity borne only by those who have no other choice. In contrast, most women who choose to be surrogates are not destitute or coerced, but are middle-class women who have already had children and want to help infertile couples achieve the gift of life. ${ }^{74}$ These women freely choose to be surrogate mothers, as a form of generosity. They do not feel that their role diminishes their personal integrity.

There is no compelling evidence to support the notion that surrogacy harms children, either by making the children of the intending couple feel abandoned by the surrogate mothers, or by making the children of the surrogate mother feel like they could be sold. In fact, surrogate mothers go out of their way to explain to their own children the special circumstances that cause them to be carrying the baby of another couple. ${ }^{75}$ Radin's attack

74. Lori B. Andrews, Beyond Doctrinal Boundaries: A Legal Framework for Surrogate Motherhood, 81 VA. L. REV. 2343, 2365 (1995).

75. Id. at 2359. 
on surrogacy rests primarily on the equation of surrogacy agreements with baby-selling, and on the assumption of inevitable commodification consequences. Surrogacy is in fact more like other forms of assisted reproductive technology and less like baby-selling, and the commodification consequences have not come to pass.

\section{B. Custody as Liability}

In viewing legal parenthood as a right, I have assumed that custody should be considered an asset. This may not always be the case, however. Although adults often view child custody as an asset to fight over, adults may also view custody as a liability. For parents who do not want added responsibility, custody means unwanted child support responsibilities. The labor model allows men to avoid the responsibilities that go with custody by not supporting gestation. If men choose to avoid custody, and hence evade child support responsibilities, the real losers are women and children. While it is beyond the scope of this Note to propose an alternative method of child support, this Section briefly summarizes two possible solutions: first, splitting the connection between support responsibility and custody, and second, providing a state system of child support.

There is something intuitively appealing about hinging support responsibilities on custody entitlement. ${ }^{76}$ Perhaps the most commonly held model is that child support is bestowed on an undeserving party, the child, who is not expected to repay the financial support. In exchange for this donation, the adult should get something in return. Since custody is viewed as an asset, adults who financially support children are entitled to custody. However, one can drive a conceptual wedge between support obligations and custodial rights. Some have argued that the support obligation derives directly from the act of sex itself, and is not tied, as many intuitively believe, to the pleasures of child-rearing. The right to raise a child, in contrast, is initially based on what one has invested in the relationship, and it is later based on one's emotional significance in the child's life. ${ }^{77}$

An alternative solution to the problem of financing single-parent childrearing is a state system of child support. There are various approaches to child support, but most systems fall between the two extremes of complete privatization and complete socialization. The current system in the United

76. The notion that rights are contingent on responsibilities may rest on older paternalistic notions of parenthood that assigned custodial rights to the father, who in turn had support responsibilities. For a description of the paternal custody model, see MiCHAEL GROSSBERG, GOVERNING THE HEARTH 235-36 (1985).

77. This analysis closely follows that suggested in Barbara Bennett Woodhouse, Hatching the Egg: A Child-Centered Perspective on Parents' Rights, 14 CARDOZO L. REV. 1747, 1818-19 (1993), which argues that while biology creates responsibility, only caretaking creates authority. 
States is closer to the privatization pole, while many European countries lie closer to the socialization pole. ${ }^{78}$ Because the American government assumes no basic responsibility for raising children, it can be asserted reasonably that the American system presently privatizes the costs of raising children. Exceptions to this basic position are public education and the federal welfare program, which has recently undergone major reform, further limiting the already limited assistance to the poorest of the poor and specifying that they may receive it only if they meet certain conditions. ${ }^{79}$ The American system actively evades responsibility for poor children by conditioning single mothers' welfare benefits on mandatory paternity proceedings ${ }^{80}$ Although family assistance programs in Europe vary to some degree, the European model of welfare can be generally described as a combination of child allowances, mothers' penșions, and subsidized day care. $^{81}$

Under the current American model, which privatizes the costs of childrearing, basing custody on caretaking and assuming the dependence of child support on custody, the labor model would wreak havoc on poor single mothers. While wealthier single mothers might be able to finance childcare with their salaries, and still have enough left over to live comfortably, a minimum-wage salary cannot pay for both day care and living expenses. A solution would be to move closer to the European model and to create a program of state-funded child support across income brackets. ${ }^{82}$

78. Nancy E. Dowd, Envisioning Work and Family: A Critical Perspective on International Models, 26 HARV. J. ON LEGIS. 311 (1989).

79. Personal Responsibility and Work Opportunity Reconciliation Act of 1996, 42 U.S.C.S. $\S 608$ (Law. Co-op. 2000). For a history of welfare reform, see GWENDOLYN MINK, WELFARE'S END 33-67 (1998).

80. 42 U.S.C.S. $\$ 608(a)(2)$.

81. See Dowd, supra note 78.

82. State-funded child support is an entire reform proposal of its own. Its proponents argue over the best type of support, ranging from cash grants to in-kind services. Compare Joan Willians, Toward a Reconstructive Feminism: Reconstructing the Relationship of Market Work and Family Work, 19 N. ILL. U. L. REV. 89 (1998) (advocating subsidized day care), with VICTOR R. FUCHS, WOMEN'S QUEST FOR ECONOMIC EQUALITY (1988) (preferring cash allowances). Reformers who have suggested state-funded child support of one kind or another have justified their proposals on various grounds. MARTHA ALBERTSON FINEMAN, THE NEUTERED MOTHER, The Sexual Family and Other Twentieth Century Tragedies (1995) (recommending state-funded child support); FuCHS, supra (advocating for child allowances and child care).

Though such a discussion is beyond the scope of this Note, I offer one rationale that reformers have given for state-funded child support. Martha Fineman has persuasively demonstrated that in privatizing the costs of child-rearing, the state has created the myth of dependent women, while masking the source of their dependency, the inherent dependency of children. FINEMAN, supra, at 161-66. Raising children is necessary for society and should be recognized and paid for as such. Children need adults to care for them, and this can be a full-time job. If that work is not rewarded, as it is not in our society, the caretakers themselves are rendered dependent on third parties for financial support. Because children are a necessary social good, supporting them is necessary work that the state should be more than willing to pursue. 


\section{IMPLICATIONS FOR SUBSEQUENT CUSTODY DECISIONS}

In this Note, I have suggested an answer to the foundational question of what constitutes legal parenthood. The model proposed is that legal parenthood is not based on mere genetic connection to the newborn, but on the labor investment in developing the fetus. What is the relevance of this theoretical framework once parenthood has vested and certain adults are recognized as parents? Does this property rationale continue to support claims of right in subsequent custody disputes as well? In short, is legal parenthood interminable? This Part seeks to address these questions.

\section{A. Subsequent Custody Decisions and Continuous Investment}

Generally, once property is acquired, it does not expire at a certain point absent an intentional transfer of ownership. ${ }^{83}$ Is it appropriate to think of the property right in children as being permanent absent intentional transfer? The difficulty with treating the right to children as a permanent right is that children grow and develop. Determining the question of initial custody, who takes the child home from the hospital, is necessary for practical reasons, but that determination should not be viewed as the final determination of custody. As children progress in their development over time, adults continue to invest in their development emotionally, physically, and financially. For subsequent custody decisions, it is insufficient to view adults' rights to children as static, the result of their investment in fetal development. Subsequent custody decisions should be based on an assessment of continuous investment in the child's development.

Determining what type of investment counts is difficult because adults invest in their children in myriad ways. They invest financially, by paying for children's basic needs; emotionally, by providing love and guidance; and physically, by performing the actual labor of supervision and caretaking. Each of these investments can be viewed as a type of labor. Physical exertion is most easily understood as labor, but it is evident that emotional interests should not be dismissed either. Money is not necessarily labor itself, but is understood to substitute for labor; the person who pays for others to provide services is considered to have provided those services. In addition, money is considered the product of labor, and hence the money-making activities that parents pursue in order to provide for their children can also be conceptualized as labor.

83. Doctrines such as adverse possession, where property rights are terminated absent intentional transfer, are the exceptions that prove the rule. For a summary of the laws of adverse possession, see 16 RICHARD R. POWELL, POWELL ON REAL PROPERTY § 91 (2000). 
Theoretically, all of these ways of investing in children should be recognized for purposes of maintaining continued parental rights. There are reasons, however, to prefer physical and emotional investment over monetary investment. The first reason is inherent to the nature of the right at issue. As Baker suggests, recognizing the emotional, and I would add, the physical, investment in children as a means of maintaining parental rights makes sense in the context of a relationship with the child, ${ }^{84}$ and as such flows naturally into the best interests of the child standard. It is generally in the best interests of the child to award custody to the parent who has invested physically and emotionally, and thus has a psychological relationship with the child, rather than awarding custody to the parent who might have been absent from the child's life except for the steady stream of financial support.

The second reason is not inherent to the right involved, but is a consequence of living in a gendered world. While there has arguably been much progress away from the antiquated myth of fathers as exclusively breadwinners and mothers as exclusively housewives, a world of complete gender equity is not yet within grasp. ${ }^{85}$ Although women constitute a great percentage of the workforce, ${ }^{86}$ they have retained primary responsibility for maintaining the household and being emotionally responsible for raising their children. ${ }^{87}$ This gendered division of parenting labor has several negative consequences. First, and perhaps most significant, scholars have attributed the gender wage gap to the fact that women are more likely to take off time for childcare than are men. ${ }^{88}$ Gendered parenting roles thus

84. Baker, supra note 45 , at $1580-81$.

85. See generally SCOTT COLTRANE, FAMILY MAN (1996) (exploring the emergence of new notions of fatherhood but noting that the United States is still far from complete gender equity).

86. ARlie Russell Hochschild, The Time Bind: WHEN WORK BECOMES HoME AND HOME BECOMES WORK 260-61 tbl.A (1997).

87. Numerous studies show that women spend much more time per week on housework and childcare than their male partners. COLTRANE, supra note 85 , at 54 (reporting that men spend between five and eight hours per week on housework, while women spend between twenty and thirty hours); KATHLEen HALl JAMIESON, BEYOND tHE DOUBle Bind 62 (1995) (arguing that men spend one-fifth the amount of time on household duties compared to their female partners, and one-third the amount of time on childcare); David H. Demo \& Alan C. Acock, Family Diversity and the Division of Domestic Labor, 42 FAM. REL. 323, 329 (1993) (finding that, on average, mothers spend forty to forty-four hours per week on household labor while their male partners spend thirteen hours); Joni Hersch \& Leslie S. Stratton, Housework, Fixed Effects and Wages of Married Women, 32 J. HUM. RESOURCES 285, 289-90 (1997) (stating that women averaged 19.2 hours of housework a week while men averaged 6.8 hours).

88. Commentators have argued that women's household labor accounts for the gender wage gap. E.g., Jane Waldfogel, Understanding the "Family Gap" in Pay for Women with Children, 12 J. ECON. PERSP. 137, 137 (1998). See generally Samuel Issacharoff \& Elyse Rosenblum, Women and the Workplace: Accommodating the Demands of Pregnancy, 94 COLUM. L. REV. 2154 (1994) (arguing that law must affirmatively accommodate pregnancy to close the wage gap brought about by women's decreased participation in the workforce due to childcare); Michael Selmi, Family Leave and the Gender Wage Gap, 78 N.C. L. REv. 707 (2000) (arguing that men must be encouraged to caretake more in order to narrow the gap). For statistics that show that women take off more time than men to care for children, see ECON. \& STAT. ADMIN., U.S. DEP'T OF 
prevent women from moving towards workplace equality. Second, the societal expectation is still largely that women will assume both career and parenting responsibilities, creating cultural pressure for both men and women to conform to these arbitrary gender roles. Men and women who do not want to conform to these stereotypes are stifled ${ }^{89}$ Third, a mother's burden is currently weightier than a father's, because mothers are expected to care for their children as well as maintain employment, while fathers are expected simply to be employed.

Recognizing monetary investment as sufficient currency to acquire parental rights allows the custodian to limit involvement with the child to a monetary relationship. This has a twofold negative effect. First, it maintains the gendered status quo by giving men no incentive to caretake. Second, it disadvantages women by not recognizing their nonmonetary contributions. Generally, women will at least initially assume the bulk of the caretaking responsibilities, and henceforth delegate and supervise those responsibilities, while men will not. Women will thus expend considerably more effort that gives them no monetary or legal advantage. Both women and men, however, will continue to be recognized legally and socially as the child's custodians.

Examined in a vacuum, there is nothing unfair or unjust about a couple deciding to divide up market and home labor and for each parent to specialize in only one type of labor. There is not even anything unjust about one person agreeing to do more than her fair share of the labor. But bargains are only fair if they are made freely. Someone who grows up in American culture would have a very difficult time making this choice on her own. ${ }^{90}$ In this country, heterosexual, sexist paradigms may rig such a choice from the start. ${ }^{91}$ When men and women are differently encouraged on the basis of their gender, those who conform to societal expectations of

COMMERCE, STATISTICAL ABSTRACT OF THE UNITED STATES 417 tbl.659 (1999), which states that $36.3 \%$ of married women with children under the age of six do not participate in the paid labor force.

89. It has been posited that sex role socialization plays a much greater role in these decisions than choice. JOAN WILLIAMS, UNBENDING GENDER 13-39 (2000).

90. Although there is a strain in feminist literature that prefers to view all of women's decisions as based on choice, e.g., Kathryn Abrams, Ideology and Women's Choices, 24 GA. L. REV. 761, 768-70 (1990); Anne M. Coughlin, Excusing Women, 82 CAL. L. REV. 1, 6-7 (1994), there is a prevalent strain that questions the freedom to choose in various situations, e.g., JERRY A. JACOBS, REVOLVING DOORS: SEX SEGREGATION AND WOMEN'S CAREERS (1989) (arguing that sex-role socialization maintains the sexual segregation of the workplace); BARBARA RESKIN \& IRENE PADAVIC, WOMEN AND MEN AT WORK (1994) (examining how the social construction of gender maintains workplace sex segregation); Vicki Schultz, Telling Stories About Women and Work: Judicial Interpretations of Sex Segregation in the Workplace in Title VII Cases Raising the Lack of Interest Argument, 103 HARV. L. REV. 1750, 1815-16 (1990); Selmi, supra note 88, at 736-43; Joan C. Williams, Deconstructing Gender, 87 MICH. L. REV. 797, 836 (1989).

91. For discussions of the role of socialization in constructing gender, see BARBARA R. BergmanN, THE ECONOMIC EMERgENCE OF WOMEN 40-61 (1986); and CYNTHIA FUCHS EPSTEIN, DECEPTIVE DISTINCTIONS: SEX, GENDER, AND THE SOCIAL ORDER 99-110 (1988). 
gendered role division have been denied a fundamental entitlement. Instead of being given the freedom to choose a path in life, they have been funneled into a path on the basis of their sex.

It is against this background that a framework for subsequent custody entitlement must be considered. Equating monetary investment with physical and emotional investment for purposes of maintaining custody simply perpetuates this gendered role division. Nothing in the custody framework encourages men and women to rethink traditional gender roles, and thus the framework absorbs and reflects the inequalities of its context. For subsequent custody decisions, therefore, only physical and emotional investment in the child's development should be credited as continuous investment.

\section{B. Social Effects of Limiting Custodial Investment to Caretaking}

While the goal of this limited notion of custodial investment would be to encourage men to invest physically and emotionally in their children, and to compensate women for doing so, changing the legal criteria for maintaining parental rights could have several possible consequences. In the best case scenario, it would encourage men who would want to keep their children in the event of divorce to adopt some of the caretaking that has traditionally been considered the mother's responsibility. Most couples do not anticipate or prepare for divorce. With one in every two marriages ending in divorce, ${ }^{92}$ however, the threat of divorce is not something most married couples can rationally ignore. Many couples plan for divorce with prenuptial agreements, but such agreements cannot determine custody of children. Rational individuals will realize that emotional investment in their children is a smart protective move. At the very least, this would reward those women who currently caretake disproportionately.

Another positive aspect of the modified labor model is that parental rights now flow naturally into the child's interests. Often, it is in the best interest of the child to stay with the parent who has invested the most emotional energy. Most often it is this parent with whom the child has developed a significant relationship. This Note has been concerned with those situations in which the child's interests do not dictate a custody determination, either because they are too difficult to determine or because they do not discriminate between either potential parent. It is in these situations that it is useful to turn to a conception of adults' rights to fill the gap. Although parental rights exist independently of children's rights, it is convenient and appropriate for them to overlap in this way.

92. E.g., TERry Lugalla, U.S. DeP'T OF COMMERCE, HouseholdS, Families, AND CHILDREN: A 30-YEAR PERSPECTIVE 8 (1992). 
The possible negative consequence of such a shift in child custody might be that women who very much want to retain custody over their children would be inhibited from entering the workforce and would instead stay home to ensure custody in the event of divorce. ${ }^{93}$ This is not a realistic fear. Although being the only parent to stay home to raise the children is the best way to ensure absolutely that one's property right will be greater than that of the other parent, this is rarely the most cost-effective method. In general, one simply need caretake more than the other spouse. Moreover, under this model, there need not always be a single custodian. If both parents have invested equally in the child, joint custody can be awarded.

Of course, these same women might then enter the workforce but make sure that they only work part-time so that they could be assured sole custody. This would still perpetuate gender inequality since these women would be caretaking more than their husbands. While this is a possibility, it is not critical to this proposal. This Note does not assume that one proposal can completely negate the effects of sex-role socialization and oblige men and women to divide their paid work and caretaking labor equally. The goal is significantly more modest, and the proposal would be successful if it contributed to the ongoing process of changing gender stereotypes.

\section{POLICY IMPLICATIONS OF THE LABOR THEORY OF LEGAL PARENTHOOD}

The labor theory of legal parenthood rewards gestational labor and contract with legal parenthood, and continued emotional and physical investment in the child with continued custody. This Part examines the incentive structures created by the proposed theory and describes one type of legislative modification that would help to allocate them fairly.

Because of the limitations of biology, men and women are differently situated with regard to childbearing. The labor theory of legal parenthood rewards women's disparate investment in fetal development with legal parenthood and allows men to acquire parenthood through contract. With regard to child-rearing, however, while biological limitations do not situate men and women differently, social stereotyping does. In response to this socially constructed difference, the labor theory of legal parenthood recognizes only continued emotional and physical investment in children for purposes of custody allocation, in an effort to encourage men to participate in more than just the monetary work of child-rearing.

93. For an articulation of the possible harmful incentives such a standard could create, see Jon Elster, Solomonic Judgments: Against the Best Interests of the Child, 54 U. CHI. L. REV. 1, 37 (1987). 
Creating incentives for men to participate more equally in caretaking is a tricky business. Caretaking is time-consuming and, at the margins, necessarily requires prioritizing some time with children over more time at the office. While requiring caretaking for continued custody may encourage men to work a little less and caretake a little more, men may not respond to the changed incentive structure. The societal pressures that encourage men to work and women to caretake may be difficult to counteract. ${ }^{94}$ Instead, women may continue to caretake and consequently achieve custody at divorce. While women's disproportionate investment would be rewarded, custody allocation would continue to be gendered.

Instead of requiring men to renegotiate completely the work-family balance for the entire duration of their child's development, this proposal requires that they renegotiate that balance for a shorter period of time, by finding six weeks during the first year of the child's life to invest in caretaking. In order to provide men a real opportunity to respond to the changed incentives associated with the labor theory of legal parenthood, under this proposal, taking parental leave creates a rebuttable presumption of continued parental involvement for custody purposes. The proposal modifies the Family and Medical Leave Act of 1993 (FMLA) ${ }^{95}$ to make parental leave a more viable option for men. While six weeks of infant care is not a guarantee of further continued investment, it is a significant investment and perhaps a more attainable goal than expecting workers and the workplace to rearrange their priorities for the entire duration of the worker's parenting responsibilites.

Currently, under the FMLA, employers are required to provide twelve weeks of unpaid parental leave. ${ }^{96}$ Amending the Act in the following three ways would give men (and women) a real option to take parental leave and give them added incentive to do so. First, adults should not be eligible for leave under the Act if they are merely biological parents, as currently designated by the Act, ${ }^{97}$ but only if they are legal parents as defined in this Note. That is, they should be eligible for the leave only if they have invested in the developing fetus. Second, parental leave should be paid for six weeks. Third, those parents who choose to take parental leave at any point during the first year of the newborn's life should gain a presumption, to be used in subsequent custody decisions, that they have emotionally invested in their child.

94. See supra notes $85-91$ and accompanying text.

95. 29 U.S.C. $\$ 2612$ (1994). For a discussion of the limited nature of the Act, see Maxine Eichner, Square Peg in a Round Hole: Parenting Policies and Liberal Theory, 59 OHIO ST. L.J. 133 (1998).

96. 29 U.S.C. $\$ 2612$.

97. Currently, adults are eligible for this leave if they have "a biological, adopted, or foster child, a stepchild, a legal ward, or a child of a person standing in loco parentis." 29 U.S.C. $\S 2611(12)$. 
This proposal recognizes and incorporates the different criteria for initial and subsequent custody. Under the modified FMLA, when adults meet the criteria for legal parenthood at the time of the child's birth, meaning that they are eligible for initial custody, they are eligible for parental benefits. When parents take advantage of these benefits and take leave during their child's first year of life, they exhibit the emotional investment that is the criterion for subsequent custody determinations. Courts then view parental presence at the crucial time of the child's first year as an indication of emotional commitment. Meeting the criteria for initial custody thus merits the benefits that can lead to a presumption of fitness for the purposes of subsequent custody disputes.

Quite conceivably, this modification of the FMLA would encourage more people to take parental leave. Paid parental leave offers a carrot to those parents who might not otherwise involve themselves in caretaking ${ }^{98}$ penalizing those who do not take the leave by not granting them the presumption of investment provides a much-needed stick. Although most women take advantage of parental leave policies, most men do not. ${ }^{99}$ This is arguably due to the same social forces that encourage working women to assume primary responsibility at home. ${ }^{100}$ Additionally, men often feel that they are perceived as less serious workers if they opt for parental leave. ${ }^{101}$ Penalizing those men who opt out of parental leave will encourage men who are themselves unwilling to take parental leave, but will also make it easier for those men who want to take a leave of absence but feel pressured to refrain from doing so. It is one thing to take parental leave to help out one's wife; it is quite another to take parental leave to assure custodial rights to one's children.

Those who have taken parental leave will be presumed to have invested in their children, and will be presumed to be fit for continued custody in cases of divorce or other custody contests. Those who have not taken parental leave will be at a disadvantage, as they lack the presumption of

98. Many men cite economic reasons for not taking parental leave. Janet Shibley Hyde et al., Fathers and Parental Leave: Attitudes and Experiences, 14 J. FAM. IssUES 616, 634-35 (1993); Martin H. Malin, Fathers and Parental Leave, 72 TEX. L. REv. 1047, 1066 (1994). Since many men earn more than their wives, it is economically more efficient for their wives to stay home. If leave were paid, the economic disincentive to caretake would be decreased.

99. According to the federal government's studies assessing the effect of the Family and Medical Leave Act, $58.2 \%$ of women and $41.8 \%$ of men took leave under the Act. COMM. ON FAM. \& MED. LEAVE, U.S. DEP'T OF LABOR, A WORKABLE BALANCE: REPORT TO CONGRESS ON FAMILY AND MEDICAL LEAVE POLICIES 92 (1996). For further discussions of gendered patterns of parental leave, see HoCHSCHILD, supra note 86, at 131; and Arielle Horman Grill, Comment, The Myth of Unpaid Family Leave: Can the United States Implement a Paid Leave Policy Based on the Swedish Model?, 17 COMP. LAB. L.J. 373, 377 (1996).

100. The plain fact of the matter is that many men view their wives (and not themselves) as being more appropriate caregivers. E.g., Joseph H. Pleck, Are "Family-Supportive" Employer Policies Relevant to Men?, in MEN, WORK, AND FAMLY 217, 230 (Jane C. Hood ed., 1993).

101. Hyde, supra note 98, at 629; Malin, supra note 98, at 1072. 
investment. Of course, a presumption is not dispositive. It can be disproved, and those who have not merited the presumption can prove through other evidence-such as time taken off from work and spent with the child, time after work, on weekends, during vacations and holidays-that they have invested. The presumption charts a middle course between being too draconian to be acceptable, and too insignificant to have any effect. Those who are serious about parenting will find six weeks to caretake during the first year of the child's life. Those who were unable to find the time during the first year can make up for it by caretaking later. Those who cannot invest any time in the child simply have less of a valid claim than competing parents who can.

There are several details of this proposal that would have to be addressed. Foremost among them is the issue of who would fund the six weeks of paid leave. Such issues, however, are beyond the scope of this Note, which does not seek to provide the nuts and bolts of workable tax scheme, but rather to suggest a direction for policy proposals that would implement the goals and insights of the labor theory of legal parenthood.

\section{CONCLUSION}

This Note offers a theory of legal parenthood that consistently and fairly allocates legal parenthood amongst competing claimants. The labor theory of legal parenthood proposes that adults merit legal parenthood through the labor they expend in childbearing. Yet in application to subsequent custody decisions, the pure labor investment theory must be modified to comport with ideals of gender equality. Pure labor investment theory fairly allocates legal parenthood by recognizing women's disproportionate physical investment in fetal development and respecting what in general are freely negotiated contractual intentions. Pure labor investment theory does not, however, fairly allocate subsequent custody. Because it recognizes monetary investment in child development, labor investment theory perpetuates gendered patterns of child-rearing. I have therefore modified the pure labor investment theory in its application to subsequent custody by recognizing only emotional and physical, but not monetary, investment in relationships with children.

Adults of both sexes desire the joys of parenting, but parenting has its costs: Pregnancy and childbirth can be debilitating, and raising children can be physically, emotionally, and financially draining. Historically, men and women have not shared these burdens equally. Recognizing the importance of investment in both legal parenthood and custody encourages both men and women to invest emotionally in their children. In the process, the labor theory transcends the gender inequalities traditionally associated with the work of bearing and rearing children. 